\title{
INTENSIFICATION OF THE DISTILLERY WASTE WATER ANAEROBIC FERMENTATION WITH HIGH METHANE CONTENS IN BIOGAS EMISSIONS
}

\author{
Victor Covaliov ${ }^{1}$, Valentin Bobeică ${ }^{1}$, Olga Covaliova ${ }^{2}$, Vladimir Nenno ${ }^{1}$ \\ ${ }^{1}$ Research Center of Applied and Ecological Chemistry of the Moldova State \\ University \\ 2 Institute of Chemistry of Academy of Sciences of Moldova
}

\begin{abstract}
The anaerobic digestion of organic substrates in agricultural waste waters, including from fruit and vegetable processing, winery, canning, etc. industries can be both the way to reduce the pollutants contents, and the source of biogas as well as an alternative energy source. The problem to which resolving this work is addressed, involves the following main issues: energy component, environmental protection, economic development and social improvement. The research involved is focused on developing a new-generation intensive ecological technology and integrated bioreactor for biogas production through the valorisation of agro-industrial wastes which are hazardous being dumped in the natural environment. The technology proposed bears a breakthrough character and is based on the use of natural phyto-catalysts introduced in the digested biomass in micro-concentrations of $10^{-3}-10^{-5} \%$. They are obtained by extraction from natural vegetable feedstock and wastes. It was shown that the phyto-catalysts proposed promote 1,5-2 times acceleration of methanogenic process and increase in biomethane contents in biogas up to natural gas level. Therefore, the capital costs for bioreactors construction and operation could be significantly reduced.
\end{abstract}

\section{INTRODUCTION}

The problem of renewable energy and environmental protection has nowadays become a major global challenge. The modern methods of energy production turned out to be devastating for the environment, not only because of the evolving greenhouse gases, nitrogen and sulfur oxides, polycyclic aromatic hydrocarbons with carcinogenic activity, but they are also dangerous to their production site, as it occurred, in particular, in case of the accident at an oil well in the Gulf of Mexico. Energy and environment problem is also relevant for Moldova, having no traditional sources of fossil fuels and, at the same time, with quite a large number of plant raw materials and agricultural wastes sources. They can be used to develop the renewable energy, in particular - in biogas technology, along with biohydrogen production, as the most pure source of energy and biomethane as a source of "green energy".

Because of the specifics of its geographical location, the Republic of Moldova is practically deprived of the possibility of using wind energy. Solar energy requires the development of related industries with high-technology solar panels, which, however, work for a limited time of solar activity. Other possible sources of energy such as biodiesel or bioethanol, require special use of large 
agricultural areas currently occupied under the industrial crops, and are not always justified economically.

The pollution of surface water with organic compounds from leachates of wastes generated by industries of agricultural products processing can become a serious environmental problem when treatment is impaired by the absence of treatment facilities, high maintenance cost of these stations or lack of energy resources for the treatment through aerobic fermentation. Such situations are quite common for developing countries or those with transition economies. For example, some small rivers from the territory of the Republic of Moldova, tributaries of Dniester river that serve as sources of water for several million people from Moldova and Ukraine, due to discharges from wine enterprises, fruit or vegetable processors and cattle farms are "dead" already before the inflow in Dniester, therefore they can bring with them substantial amounts of organic pollutants. This situation, as well as the deficit of energy in the country has motivated the development and proposal of a new approach to management of liquid wastes generated by producers of wine, beer, sugar, alcohol, yeasts, meat, dairy, potatoes, fruits, vegetable and other raw materials containing carbohydrates (mono- and oligosacharides, starch, pectin, etc.) and other organic substances that under the certain conditions undergo fermentation (Covaliov V., Ungureanu D. et al. 2012).

At the same time, anaerobic fermentation of organic substrates in waste waters from the aforementioned industries can be not only the way to reduce the pollutants contents, but the source of biogas as well. A variety of biomass resources can be used to convert to energy. They can be divided into four general categories: (i) energy crops, including herbaceous energy crops, woody energy crops, industrial, agricultural crops and aquatic crops; (ii) agricultural crops and aquatic crops; (ii) agricultural residues and waste: crop waste and animal waste; (iii) forestry waste and residues: mill wood waste, logging residues, trees and shrub residues; (iv) industrial and municipal wastes: municipal solid waste, sewage sludge and industry waste (Ni M., Leung D. et al., 2006).

The technologies and equipment available so far do not ensure the biogas obtaining from the above materials with the maximal possible yield. Only $30-60 \%$ of organic admixtures are transformed in biogas, and the methane contents in biogas in most cases do not exceed $60 \%$. To reach these indicators, the thermophilic conditions are most often needed for anaerobic fermentation $\left(45-55^{\circ} \mathrm{C}\right)$, which requires to return and consume of the most part of the energy obtained. Resolving of the biogas production increase problem from agricultural wastes must be based on improvement of technological parameters (reducing of expenditures, efficiency increase, etc.), equipment and flow sheets, and also the development and application of novel technologies, considering the ecological safety.

Thus, the realization of the conditions for microbial and biochemical processes can be achieved through the innovative scientific and technical solutions, taking into account the achievements of related scientific disciplines, including the processes and apparatuses of chemical technology, environmental chemistry, electrochemistry. To ensure the effective combination of biochemical and physico-chemical processes in order to accelerate the 
digestion of organic substrate and increase the efficiency of biogas technology, it is necessary to fully explore the factors responsible for these processes and to develop the innovative methods of fermentation wastewater treatment, to intensify the processes promoting the increase in biomethane yield and biohydrogen, as a sources of renewable energy, to improve the performance of anaerobic wastewater treatment and to increase the value of resulting sediments that may be further used as organic-mineral fertilizers, as well as food additives for cattle feeding. All this will enable the biogas technology to become more efficient and cost effective.

\section{GENERAL APPROACH}

There are ten specific enzymes that are characteristic for the methanogenesis process, due to which the formation of methane proceeds from carbon dioxide and hydrogen under the anaerobic conditions, realized with the methanogenic microorganisms. According to the actual tendencies, five bacterial groups are involved in the production of anaerobic methane, which are capable to be incorporated in the four stage process, the stages being dependent on each other:

1) Enzymatic hydrolysis of low soluble organic substances up to the formation of substances with more simple bonds, during the development of a aerobic bacterial group at the optimal $\mathrm{pH}=6,5-7,6$.

2) Acid stage effectuated by the heterotrophic group of microorganisms, for which carbon passed into the mixture and transformed in organic substances with simple bonds serves as a nutrition source, results in the obtaining of volatile fatty acids, aminoacids, alcohols and hydrogen and carbon dioxide as well.

3) Acetogenic stage, proceeding due to two bacterial groups: first is in the form of acetate with the emission of hydrogen from soluble substances on the stage preceeding to the formation of acids, and the second acetogenic bacterial group ensure the transformation of volatile fatty acids, which dissociate into iono-acetates, hydrogen cations and are further used for $\mathrm{CO}_{2}$ recuperation.

4) Methanogenic stage - methane formation from acetic acid, and as a result of a reaction of hydrogen and carbon dioxide recuperation with methane bacteria, which transform the methane in two ways - acetate division and carbon dioxide reducing with hydrogen. Anaerobic-strictly anaerobic bacteria are very sensible to the environment at the optimal $\mathrm{pH}=7-7,5$, although they can work at $\mathrm{pH}=9-10$.

The mechanism of the methagen's energetic processes is not decoded yet, however the general principal statements have been established. Obtaining of energy, at least during the oxidation of $\mathrm{H} 2$, associated with the reduction of $\mathrm{CO}_{2}$, is connected with the functioning of the electron-transport system, involving dehydrogenases, electron carriers and reductases. Hydrogenase and formiatdehydrogenase have been identified as dehydrogenases. The specific enzymes are typical for the methanogenesis, due to which the methane formation occurs from carbon dioxide and hydrogen with the methanogenic microorganisms under the anaerobic conditions. In total there are ten such enzymes. The detailed review regarding the structure and functions of the 
enzymes involved in the methane synthesis from carbon dioxide and molecular hydrogen was performed recently (Shima S. et al. 2014).

A number of enzymes and natural biostimulators (belonging to the class of plants growth stimulators, such as scvalen, betulinol, etc.), isoprene compounds, were preliminary tested for the acceleration of biochemical hydrolysis of refractory compounds in the distillery grains. The better results were obtained with using of biostimulators.

The proposed new approach nvolves the development and testing of type new of biologically active micro- and nano-structural additives to stimulate the biochemical processes and manage them, with the scope to intensify the anaerobic processes of biomethane production and purification on the fermentation of hard degraded raw material and cellulose (Covaliov V., Bobeica V. et al 2012). As stimulating biologically active substances (phyto-catalysts), which might improve the microbiological activity, accelerate the methanogenesis process and enhance the biomethane yield, the isoprenoids, hydrocarbons of triterpene series of natural origin, alkaloids and other compounds were tested which exert the selective action on the biogas emission. These substances have been selected, considering their biological activity, simplicity of synthesis and/or extraction from the available raw materials.

\section{EXPEIMENTAL SET-UP}

The biochemical processes and, specifically, the effect of bioactive substances on methanogenesis have been studied using the especially developed set of four bioreactors (Fig.1).

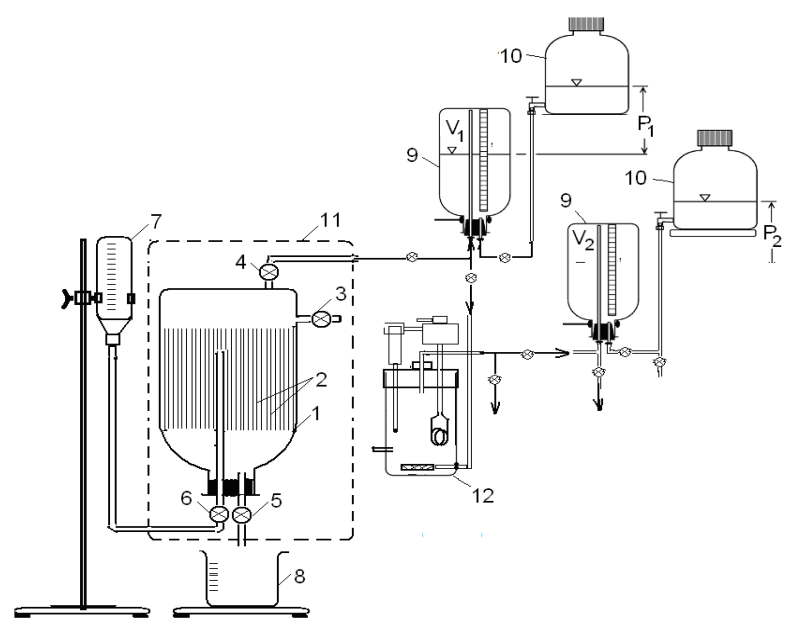

FIGURE 1. Scheme of the bench-scale bioreactor: 1 - bioreactor; 2 - package for mictroflora immobilization; 3 - 6 - valves; 7 - reservoir four nutrition solution;

8 - glassware; 9, 10 - reservoirs; 11 - thermostate; 12 - biogas purification device.

The overall volume of each bioreactor is $5000 \mathrm{~cm}^{3}$, the useful volume -3500 $\mathrm{cm}^{3}$. The equipment consists of a bench-scale bioreactor 1 , placed in the thermostatically controlled reservoir, devices to remove and control the volume 
of obtained biogas, formed sludge and purified liquid. Biogas obtained in bioreactor 1 was accumulated in calibrated reservoir 9, displacing water into the reservoir 10. Parameters of accumulated biogas were controlled - volume $\left(\mathrm{V}_{1}\right)$ and pressure $\left(P_{1}\right)$, which were measured by the water levels' difference. After the amount of biogas necessary for the experiment is accumulated, the biogas valve 4 was closed. With the increasing of levels difference in reservoirs 9 and 10 , the pressure in the reservoir 9 reached the level necessary for the gas passing through the purification device 12 .

The liquid introduced from the water storage reservoir 10, displaced the gas from the calibrated reservoir and will direct it to purification device with necessary pressure and flow. The purified gas was collected in similar reservoir, consisting of calibrated reservoir 9 and water reservoir 10. At the outlet of gas purification device, the volume $\left(\mathrm{V}_{2}\right)$, pressure $\left(\mathrm{P}_{2}\right)$ and gas temperature were controlled again. The equipment made it possible to control the operation of different biogas purification devices, logging them into the scheme one-by-one. To ensure the additional surface for microflora immobilization, the grapevine rods were introduced in bioreactor, with the total package surface of $8000 \mathrm{~cm}^{2}$. The experiments were conducted under anaerobic conditions, the temperature will be maintained as of $33,0 \pm 0,1^{\circ} \mathrm{C}$.

Cultivation and adaptation of anaerobic microorganisms was performed, following the conventional procedure with sludge inoculation from the Chisinau Municipal waste water treatment plant. The biomass growth of methanogenic microorganisms was carried out in bioreactors within one month under the controlled process parameters, with permanent introducing of the nutrition mixture containing sugar and milk (3:1). Indicator of acidophilic process transition to methanogenic one in bioreactors was the achievement of $\mathrm{pH}=7,4$ 7,6 and stable amount of the emitted gas.

The nutrient synthetic substrate contained the following components, $\mathrm{g} / \mathrm{l}$ : $\mathrm{KH}_{2} \mathrm{PO}_{4}-0,4 ; \quad \mathrm{K}_{2} \mathrm{HPO}_{4}-0,2 ; \mathrm{NH}_{4} \mathrm{Cl}-1 ; \mathrm{NaHCO}_{3}-1,8 ; \mathrm{Na}_{2} \mathrm{CO}_{3}-0,5 ;$ $\mathrm{CaCl}_{2} \cdot 2 \mathrm{H}_{2} \mathrm{O}-0,05 ; \mathrm{MgSO}_{4} \cdot 7 \mathrm{H}_{2} \mathrm{O}-0,1$; yeasts extract -1 ; resurine-indicator - 1 ; sodium ditoinate till decolorizing; $\mathrm{pH}=7,5$. During the experiment, the amount of anaerobic bacteria and identification of their groups was detected, biogas amounts were measured and analysed with chromatometric method, COD and BOD of the initial and fermented waste water were determined, and also the concentrations of biogenic substances - nitrogen and phosphorus, suspended solids, alkalinity, volatile fatty acids, contents in organic matter, ratio C : N. At the same time, the work was carried out on the selection and testing of type new of stimulating substances, in order to intensify the bacteria growth by contact method under the laboratory conditions. The individual and joint effect of additives was assessed.

Characteristics of initial distillery vinasse and sewage sludge. The distillery vinasse is a liquid yellowish suspension, resulted as a waste from the distillery processes. It has the humidity $91,3-91,6 \%$, with insignificant contents in dry substance $-8,4-8,8 \%$ and acid $\mathrm{pH}(\mathrm{pH}=5,4)$. The total carbon contents makes $4,25 \%$ of the wet and $49,5 \%$ of dry mass of the waste. The distillery grains are characterized with the high COD and $\mathrm{BOD}_{5}$ values - 28250 and $17800 \mathrm{mgO} / \mathrm{l}$, accordingly. The initial vinasse contains the aerobic heterotrophic microorganisms - 7,39 CFU (colony-forming units) $\cdot 10^{6} / \mathrm{ml}$. Following the 
neutralization and alkalinization, the vinasse was used as a medium for cultivation of methane-forming bacteria. The post-distillery vinasse also contained the substances with organic carbon (pentoses and organic acids), products of monosaccharides decomposition, as well as the liquid wasted from the spirits and furfural rectification. In dependence on the type of raw material processed, it may contain components shown in the Table 1.

TABLE 1. Chemical composition of post-distillery vinasse, $\%$

\begin{tabular}{|c|c|c|c|}
\hline Indexes & Chemical structure & $\begin{array}{l}\text { Wood and } \\
\text { molasses }\end{array}$ & $\begin{array}{l}\text { Wood and } \\
\text { grains wastes }\end{array}$ \\
\hline $\begin{array}{l}\text { Soluble substances } \\
\text { (PB) }\end{array}$ & & $0,49-0,65$ & $0,51-0,53$ \\
\hline Furfural & & $0,0005-0,002$ & $0,0005-0,001$ \\
\hline Oxymethyl-furfural & & $0,059-0,080$ & $0,064-0,066$ \\
\hline Levulinic acid & $\begin{array}{l}\mathrm{HOOC}-\left(\mathrm{CH}_{2}\right)_{2}-\mathrm{CO}- \\
\mathrm{CH}_{3}\end{array}$ & $0,301-0,384$ & 0,302-0,391 \\
\hline $\begin{array}{l}\text { Lignofuranic } \\
\text { substances }\end{array}$ & & $0,286-0,304$ & $0,302-0,311$ \\
\hline Organic acids & & $0,38-0,57$ & $0,63-0,68$ \\
\hline $\begin{array}{l}\text { Absolutely dry } \\
\text { substance }\end{array}$ & & $1,60-1,81$ & $1,46-1,49$ \\
\hline Monosaccharides & & $0,47 \pm 0,12$ & $0,405 \pm 0,06$ \\
\hline Arabinose & & $0,071 \pm 0,014$ & $0,063 \pm 0,013$ \\
\hline Xylose & & $0,40 \pm 0,10$ & $0,388 \pm 0,08$ \\
\hline $\mathrm{COD}, \mathrm{mg} \mathrm{O}_{2} / \mathrm{dm}^{3}$ & & $21569-23137$ & $22333-23040$ \\
\hline $\mathrm{pH}$ initial & & $3,9-4,5$ & $3,7-4,3$ \\
\hline
\end{tabular}

The sewage sludge was used as a source of methanogenic microorganisms. According to the microbiological studies, the sewage sludge is a material with slightly alkaline reaction $(\mathrm{pH}=7,5)$, and high contents in organic matter (an average of $21,3 \%$ ). As a result, sludge had a high number of bacteria, $\mathrm{CO}_{2}-$ producing capacity and dehydrogenase activity. This determined the high number of bacteria, $\mathrm{CO}_{2}$-producing capacity of the sludge and its dehydrogenase activity (Table 2 ).

TABLE 2. Microbiological and biochemical characteristics of initial sewage sludge

\begin{tabular}{|c|c|c|c|c|c|c|c|}
\hline MB & $\begin{array}{c}\text { Heterotrophic } \\
\text { bacteria }\end{array}$ & Nocardia & $\begin{array}{c}\text { Actino- } \\
\text { mycetes }\end{array}$ & $\begin{array}{c}\text { Methane } \\
\text { bacteria }\end{array}$ & Fungi & $\mathrm{CO}_{2}$ & $\begin{array}{c}\text { Dehydrogenase } \\
\text { activity }\end{array}$ \\
\hline $\begin{array}{c}\mathrm{mg} \\
\mathrm{C} / \mathrm{g}\end{array}$ & \multicolumn{3}{|c|}{$\mathrm{CFU} \cdot 10^{6} / \mathrm{g}$} & \multicolumn{2}{c|}{$\mathrm{CFU} \cdot 10^{3} / \mathrm{g}$} & $\begin{array}{c}\mathrm{mg} \\
100 \mathrm{~g} \\
/ 24 \mathrm{~h}\end{array}$ & $\begin{array}{c}\mathrm{mg} \mathrm{TPF} / 10 \mathrm{~g}^{\prime} \\
24 \mathrm{~h}\end{array}$ \\
\hline 2,5 & 1286,8 & 249,3 & 22,8 & 350 & 5,4 & 1,91 & 11,8 \\
\hline
\end{tabular}


It was found that that sewage sludge is a biologically active material, in which bacteria are predominant among the microbial community. The number of fungi is insignificant. Microbial carbon contents in the dry waste is $2,5 \mathrm{mg} \mathrm{C} \mathrm{g}^{-1}$. One tone of waste contains about $5,0 \mathrm{~kg}$ of dry microbial biomass. The sewage sludge contains methane bacteria in the amount of $350 \cdot 10^{3} \mathrm{CFU} \mathrm{g} \mathrm{g}^{-1}$.

\section{RESULTS AND DISCUSSION}

The comparative analysis of proposed additives to be introduced in biochemical fermentation process of the distillery grains was performed, and the most efficient were selected for further research. First, the change in biogas composition during the distillery grains fermentation process without additives was studied, using the gas chromatography, It was shown that the anaerobic fermentation starts with hydrogen release, and then the release of carbon monoxide (CO) begins. Hydrogen content in the emitted gas was gradually increasing, reaching the maximum of $7-10 \%$ in $4-6$ days. Then the decrease in both gases contents is observed. They are transformed into methane and in 1820 days its contents in biogas increases to $60-65$ vol. $\%$.

A number of biologically active additives were tested, including the oil extract of amaranth (biologically active substance is squalene), isoprenoids (biologically active substance is betulinol), etc. All the studied additives were introduced in bioreactor in concentration of $0,0005 \%$ jointly with the distillery grains (Covaliov V., Covaliova O. et al., 2011). The indicators were measured after the two nutrition cycles and following three nutrition cycles. The total length of one experiment was 300 hours (12,5 days). One bioreactor was a control one, in which the biogas yield was measured without the introduced additives.

\section{Effect of squalene (amaranth seeds) and betulinol (birch-tree bark).}

It was found that the oil extract of amaranth (squalene) with concentration of 0,0005\% provoked an increased biomethane yield in biogas, reaching 93-97\%, compared to the control which was $68-70 \%$. At the same time, the additive of squalene did not render the significant effect on the biochemical process rate. Introduction of isoprenoids (betulin derivatives) in concentration 0,0005\%, caused more than two times increase in the biogas emission rate, reaching 12,5-15,0 $\mathrm{ml} / \mathrm{h}$, and has 3-4 times increased the methanogenesis efficiency. Both amaranth and betulinol were found to stimulate the growth of heterotrophic aerobic bacteria.

The biological activity of substances in the methanogenic process depends on their availability to microorganisms. As the amaranth oil in the seeds is in the homogeneous state in the inter-cellular space, it is possible to avoid the squalene extraction operation from the seeds. Thus, the seeds can be used in the crashed state in the biochemical fermentation processes. This would make the process cheaper. If the phyto-catalyst within the vegetable cells made of the dense cellulose, as in the case of betulinol, they are not easily available for microorganisms. Therefore, betulinol extraction is needed.

The behavior of the mixture of these active additives on the methanogenic process was tested. The initial suspension of biologically active additives contained $1 \mathrm{mg}$ of betuline and $1 \mathrm{mg}$ of amaranth oil per each $\mathrm{ml}$ of active 
additives contained ( $0,2 \%$ with regard to the active substances). The following concentrations of biologically active additives have been selected for the research: $0,00025 \%, 0,0005 \%$ and $0,001 \%$, which was equivalent to the introduction in bioreactor of each 2,5,5,0 and $10 \mathrm{mg}$ of active substance per each liter of distillery grains.

The results of the study of various concentrations of biologically active additives on the formation rate, yield and general volume of biogas, resulted from the methanogenic process, have shown that the joint application of two phytocatalysts essentially increases the rate of gas release (3,5-4 times). The increase in phyto-catalysts concentration higher than $5 \mathrm{mg} / \mathrm{l}$ is not rational, as it is not accompanied with further gas emission rate acceleration. The analysis of qualitative and quantitative composition of biogas has shown that the contents in methane made $58-60 \%$ in the control sample, whereas in the gas produced with introduction of phyto-catalysts, there are $90-92 \%$ of methane. The process indicators, obtained in the certain time periods, and the average gas emission rates are summarized on the Table 3.

TABLE 3. Biochemical process indicators

\begin{tabular}{|c|c|c|c|c|c|c|c|c|c|}
\hline \multirow{2}{*}{\multicolumn{2}{|c|}{$\begin{array}{l}\text { Anaerobic } \\
\text { digestion } \\
\text { time, hours }\end{array}$}} & \multicolumn{8}{|c|}{ Biogas release rate and the efficiency of methanogenic process } \\
\hline & & \multicolumn{2}{|c|}{$\begin{array}{l}\text { Control }- \text { without } \\
\text { additives }\end{array}$} & \multicolumn{6}{|c|}{ Concentrations of the mixture of additives betulinol+squalene, $\%$} \\
\hline \multirow[b]{2}{*}{ Initial } & & \multirow[b]{2}{*}{$\begin{array}{l}\text { Volume, } \\
\mathrm{ml}\end{array}$} & \multirow[b]{2}{*}{$\begin{array}{l}\text { Rate, } \\
\mathrm{ml} / \mathrm{H}\end{array}$} & \multicolumn{2}{|c|}{$0,00025 \%$} & \multicolumn{2}{|l|}{$0,0005 \%$} & \multicolumn{2}{|l|}{$0,001 \%$} \\
\hline & & & & $\begin{array}{l}\text { Volume, } \\
\mathrm{ml}\end{array}$ & $\begin{array}{l}\text { Rate, } \\
\mathrm{ml} / \mathrm{H}\end{array}$ & $\begin{array}{l}\text { Volume, } \\
\mathrm{ml}\end{array}$ & $\begin{array}{l}\text { Rate, } \\
\mathrm{ml} / \mathrm{H}\end{array}$ & \begin{tabular}{|l} 
Volume, \\
$\mathrm{ml}$
\end{tabular} & $\begin{array}{l}\text { Rate, } \\
\mathrm{ml} / \mathrm{H}\end{array}$ \\
\hline $0-18$ & 18 & 100 & 5,6 & 250 & 13,9 & 325 & 19,1 & 300 & 16,7 \\
\hline $19-25$ & 7 & 40 & 5,5 & 75 & 10,7 & 75 & 10,7 & 100 & 14,3 \\
\hline $26-45$ & 20 & 110 & 5,5 & 50 & 2,5 & 0 & 0 & 0 & 0 \\
\hline $46-69$ & 24 & 120 & 5,0 & 0 & 0 & 0 & 0 & 0 & 0 \\
\hline $70-93$ & 24 & 75 & 3,1 & 0 & 0 & 0 & 0 & 0 & 0 \\
\hline Total & & 445 & 48 & 37 & 83 & 10 & 160 & 400 & 16.0 \\
\hline
\end{tabular}

The data obtained have demonstrated that the additives in the methanogenic process make it possible to obtain practically the same biogas volume during 25 hours, compared to the 93 hours in the control test, the biogas emission rate being thus about 4 times higher.

The explanation of this phenomenon can be connected with the molecular structure of these compounds. Intensification of anaerobic fermentation seems to be ensured due to the antioxidant, antihypoxant and amnimutagenic activity of the additives of betulinol, which extract stabilizes the cellular membranes of microorganisms, enhances the stability o their cells, increases the stability of their cells with regard to the hypoxia (oxygen lack), decreases the peroxide oxidation of lipids and prevents to the damage of cellular membranes. This makes it possible to accelerate the running of biochemical methanogenic processes and increase the biogas yield.

Introduction in biochemical digestion process of squalene (biochemically active substance, which has a property to capture oxygen and saturate the microorganisms tissues with it during the simple biochemical interaction with water) ensures the more complete running of methanogenic process. In its turn, 
this promotes the higher biogas yield and higher contents in biomethane in it. In the presence of the mixture of squalene and betulinol or its derivatives, the synergetic effect appears, that promotes the more complete running of methanogenic process and therefore, more efficient anaerobic fermentation of organic substrate.

An increase in the dose of biologically active substance from 5 to $10 \mathrm{mg} / \mathrm{l}$ increased the maximal rate of gas emission from one to four days. In the case of regular introduction of amaranth, it becomes possible to keep the maximal gas emission rate during the entire process. It is to be mentioned that the introduction of bioactive agent containing betulinol, inhibits the methanogenic process, however, adding of betulinol and squalene jointly, will render the positive effect, improving the efficiency of biochemical process. This different effects of additives may be explained by the different mechanisms of their influence on the organic substrate fermentation.

At the same time, it was shown that the introducing of microadditives in the extremely low concentrations into the biochemical fermentation process has a number of advantages. Thus, the microorganisms do not cause a damage to the environment, and help to reestablish and maintain the ecological balance. They do not exert any unfavorable modifying effect on microorganisms, present at the treatment plants, and do not bring them any harm.

The possibility of using of the raw products as phyto-catalysts was established crushed seeds of amaranth, containing squalene, birch-tree cortes containing betulinol, in the biochemical methanogenic technology. Still, the efficiency of their action is lower, compared to the pure extracted products, which makes it possible to transfer the heterogeneous biochemical process into the homogeneous conditions.

Acknowledgement: This research has been performed under the STCU (American Science and Technology Center in Ukraine) Grants \# 5832 and \# 5998.

\section{REFERENCES}

1. Covaliov V., Bobeica V., Ungureanu D., Covaliova O., Duca Gh., Nenno V., Senicovschaia I. (2012) 'Method of anaerobic treatment of liquid organic wastes' Patent No. 4189 MD. Publ BOPI, No.12.

2. Covaliov V., Covaliova O., Ungureanu D., Nenno V., Clichici I. (2011) 'Reactor for biogas production'. Patent Nr. 4130 MD. Publ. BOPI, Nr.10.

3. Covaliov V.V., Ungureanu D.V., Covaliova O.V. (2012) 'Theoretical and applied aspects of improving the biogas technology'. In: Problems of the regional power engineering, Institute of Power Engineering ASM, Chisinau, pp. 3-17.

4. Ni M., Leung D., Leung M., Sumathy K. (2006) 'An overview of hydrogen production from biomass' Fuel Proc.Technol. Vol.87, pp. 461-472.

5. Shima S. (2014) 'Enzyme chemistry of methanogenesis and anaerobic oxidation of methane'. Proc. Max Plank Inst. For Terrestrial Microbiol. Vol. 52, pp.307-312. 